\title{
Journal of Entrepreneurship \& Organization Management
}

\section{Public Private Partnership and the Dynamics of Development in the $21^{\text {st }}$ Century: The Kogi State Experience}

\section{Oko $\mathrm{O}^{1^{*}}$, Nnachi $\mathrm{C}^{1}$ and Robert MA ${ }^{2}$}

${ }^{1}$ Department of History and International Studies, Federal University Lokoja, Kogi State, Nigeria

${ }^{2}$ Director General Kogi State Bureau for Public Private Partnerships, Kogi State, Nigeria

"Corresponding author: Oko O, Department of History and International Studies, Federal University Lokoja, Kogi State, Nigeria, Tel: +08100330277; E-mail: okootuc@gmail.com

Received date: Aug 23, 2018; Accepted date: Nov 19, 2018; Published date: Nov 27, 2018

Copyright: ( 2018 Oko O, et al. This is an open-access article distributed under the terms of the Creative Commons Attribution License, which permits unrestricted use, distribution, and reproduction in any medium, provided the original author and source are credited.

\begin{abstract}
Historically, the failure of government to launch an effective and efficient welfare state in the 1960s and 70 s showed its limitations as a sole problem-solving entity. Consequently, the challenges which besought the implementation and realization of the objectives of the privatization and commercialization policy have shown that outright privatization and commercialization of public enterprises, does not solved the plethora of developmental challenges facing the country. However, sustained and increasing enthusiasm for public private partnerships is built on the premise that public policy problems, addressed exclusively by the public sector in the past are becoming more complex and need to be solved using a collaborative endeavor that takes advantage of the specialization and professional expertise offered by the private, semi-private and nonprofit sectors. The Bureau of Public Private Partnership (BP3) is a development initiative adopted by the Kogi State government for development through effective integration and interaction between government and private institution. This initiative is premised on the dynamics of development in the $21^{\text {st }}$ century and the fact that there cannot be development without an active private sector participation to grow the economy. The practice therefore encourages private individuals to design projects; programs and development plan which will receive government backing in its implementation but which must also conform to the standards and regulations of the government. The adoption and implementation of the (PPP) act by some states have given a new impetus to development both to rural and urban areas. This paper chronicles the success story of the policy in Kogi State and contends that the success recorded by this policy in the state makes it a viable option for development and should be adopted and given more attention by other states. The methodology encompasses historical and comparative approach using primary and secondary sources of data.
\end{abstract}

Keywords: Public private partnership; Development; Kogi state

\section{Introduction}

Since the attainment of political independence in 1960, infrastructural development has been a major concern and preoccupation of successive government, yet the evidence on ground shows that these efforts are at best superficial other than substantial. The failure of government to launch an effective and efficient welfare state in the 1960s and 70s showed its limitations as a sole problemsolving entity. Consequently, the challenges which besought the implementation and realization of the objectives of the privatization and commercialization policy have shown that outright privatization and commercialization of public enterprises, has not solved the plethora of developmental challenges facing the country. Kasim and Okeafor argued that it was because of this ugly trend that the Federal Government of Nigeria through the infrastructure Concession Regulatory Act 2005 introduced Public-Private Partnership (PPP) as a way of enhancing infrastructural development [1]. This initiative is premised on the fact that there cannot be effective development without an active private sector participation to grow the economy. The practice therefore encourages private individuals to design projects; programs and development plan which will receive government backing in its implementation but which must also conform to the standards and regulations of the government.
The adoption and implementation of the (PPP) act by some states have given a new impetus to development both to rural and urban areas. Since the creation of Kogi state in 1991, there has been a continuous effort by the government to facilitate development in the state. As an old colonial city, Kogi state environment is replete with a plethora of colonial infrastructure and other historical monuments and resources which have been largely underdeveloped. All indices for favorable investment ventures are prevalent in Kogi state. From security to raw materials, agriculture, to mining, commerce and trade, manufacturing, nodal transportation, tourism, and leisure, ICT, health, financial, services, consultancy, and many more...out of the 37 profile solid and industrial minerals in Nigeria, 27 exist in Kogi State in commercial quantities including coal, Dolomite, feldspar, bauxite, iron-ore, Gold, petroleum, clay, tar and limestone but these resources remain largely untapped and undeveloped [2].

The Bureau of Public Private Partnership (BP3) is a model development initiative under the public private partnership adopted by the Kogi State government for development through effective integration and interaction between government and private institution. This initiative is premised on the fact that there cannot be development without an active private sector participation to grow the economy. This paper chronicles the success story of the policy in Kogi State and contends that the success recorded by this policy in the state makes it a viable option for development and should be adopted and given more attention by other states. 


\section{The Dynamics of Development in the Twenty First Century}

The dynamics of development in the twenty first century is a concept which describes the changing pattern and roles of stakeholders in the development of the economy that is how the critical infrastructures which are needed to brand a nation developed are provided for. It typically shows how the responsibility of infrastructural development of a nation keeps evolving and devolving on certain arms and also discusses the challenges inherent in such dynamics. Its focus is to show the various roles which various sectors of an economy plays in the overall development of a national infrastructure.

Public Private Partnership is therefore an infrastructure led development made possible through combined human and material effort of both public and private sectors. Sullivan and Sheffrin noted that infrastructure is the basic physical and organizational structures needed for the operation of a society like industries, buildings, roads, bridges, health services, governance and so on. It is the enterprise or the products, services and facilities necessary for an economy to function [3]. Historically, the failure of government to launch an effective and efficient welfare state in the 1960s and 70s showed its limitations as a sole problem-solving entity. It is in the light of this dismal performance of the public sector projects and services, the high cost of executing them and the attendant corruption and mismanagement that the Nigeria government ventured into various forms of partnership with the private sector with a view to ameliorating most of the problems associated with public projects and service delivery in Nigeria. Ugwu observed that giving the failure of state led and dominated development approach of Nigeria and most African states after independence, the need for ideological shift from a welfare or social state to a capital or market oriented economy where the private sector will play significant role in the economy began to emerge. This development was fast tracked by the eventual collapse of socialism with the disintegration of the Soviet Union and consequent dominance of capitalism as the world economic system. The collaborative management style between the private sector and public sector became much prominent with the New Public Management (NPM) approach that started to make waves in the 1980s and 1990s of which public-private partnership is a core feature [4]. Olaopa argues forcefully that this failure can partly be attributed to the image of government as the doers and provider of all. Public-Private Partnership (PPP) aims at changing government and its public services from the old, big, rule bound, command and control, unresponsive and inefficient organization, to one that is lean, decentralized, effective, creative and responsive. Government does not have to do everything, it should do what it is best placed to do-setting development agenda and overseeing its actualization [5]. It is this background that explains the imperativeness of a new paradigm in infrastructural development. The dynamics of development in the 21st century, therefore, is a concept which explains the reasons for the failure of governments in shouldering the responsibility of overall infrastructural development of a nation and makes an argument for a strong alternative which is directly corroborative of government responsibilities.

Consequently, the challenges which besought the implementation and realization of the objectives of the privatization and commercialization policy have shown that outright privatization and commercialization of public enterprises, does not solved the plethora of developmental challenges facing the country. However, sustained and increasing enthusiasm for public private partnerships is built on the premise that public policy problems, addressed exclusively by the public sector in the past are becoming more complex and need to be solved using a collaborative endeavor that takes advantage of the specialization and professional expertise offered by the private, semiprivate and nonprofit sectors. However, it is within this new frame of responsibility for both government and private sectors that the dynamics of development especially in the twenty first century is made most manifest. The dynamics, although not a recent adventure, is an antithesis to the long standing view of government as the sole agent of development. Even welfarist states communist and socialist's states are begging to think on and adopt various approaches to their development as a result of the inherent limitations in the capacity of government to effectively deliver on this role.

Moreover, the idea is consistent with the various challenges and increasing complex nature of societies in the twenty first century. Essentially it tries to show how the changes in societies preempt changes in government approaches to societal issues of concern. The adoption of this policy in Kogi state is a clear reflection of the government's realization of its limitations in ensuring overall development and its readiness to change the long standing paradigm about development and adopt a composite approach. It is within this framework that nations are beginning to recues to the PPP as a new paradigm to development. Oyedele observed that this phenomenon has been globally seen by many as the new economic paradigm. India has benefitted a lot in infrastructure provision by the private sector through PPP. Public Finance Initiative/Public Private Partnership (PFI/ PPP) is a key policy instrument that is being used to transform public services [6]. A conceptual clarification of Public Private Partnership will form the subject of the subsequent sub-heading of this study.

\section{Conceptualizing Public Private Partnership}

The idea of a public private partnership entails collaboration between government and private capitalist investors in the development of a nation. The practice is pronounced only in capitalist inclined nations where individuals are allowed to venture into business for profit making although in a government regulated environment. This approach to development unveils the inherent limitations in both public and private enterprises in driving development. It tends to make one dependent on the other in other to ensure the delivery of quality and quantity services to the people and thereafter serves as a melting pot for the breeding of new policies and ideas for development acceleration. Its origin lies in the failure of governments to champion solely the responsibilities of development which precipitated the inclusion of the private sector.

Conceptually, the idea of a public private partnership is heuristic and elusive. Various scholars and bodies have given different definitions and interpretations to the idea. Some scholars define the term as normal contracts or as privatization of public service delivery, while others argue that they are a new governance tool with joint decision making in absence of a hierarchical principal agent relationship. Integrating the different perspectives, A public private partnership is a legally-binding contract between government and business for the provision of assets and the delivery of services that allocates responsibilities and business risks among the various partners. In a P3 arrangement, government remains actively involved throughout the project's life cycle. The private sector is responsible for the more commercial functions such as project design, construction, finance and operations [7]. Hodge and Greves offered a broad definition of the concept, according to them, public private partnership 
Page 3 of 5

are loosely defined as cooperative institutional arrangements between public and private sectors [8].

More so, Kashim and Okafor opined that $\mathrm{c}$ describes a government services or private business venture which is funded and operated through a partnership of government and one or more private sector companies [1]. In the words of Savas, Public-Private Partnership refers to any arrangement between a government and a private sector in which partially or traditionally public activities are performed by the private sector [9]. The Public Private Partnership Reference Guide Version, 2.0 defines the concept as a long-term contract between a private party and a government entity, for providing a public asset or service, in which the private party bears significant risk and management responsibility, and remuneration, is linked to performance [10]. A Public-Private Partnership (P3) is an arrangement between a public body or agency (federal, state, or local) and a private sector entity to deliver a service or facility for use by the public. While the public body and private sector entity share resources and expertise, both parties also jointly commit to an approach by which certain risks and rewards are shifted from the public body to the private entity [11]. In its simplistic sense, the Public Private Partnership can be conceived as a developmental approach which emphasizes role sharing between government and private investors. It is a form of symbiotic process of development. Under the P3 model, the skills and assets of each sector (public and private) are shared in delivering a service or facility for use by the general public, with a greater reliance upon the private entity. The risk and rewards which accrues to such project is shared according each according to their contribution.

The central feature of this policy is its collaborative and contractual postures which are performance based flexibility, stakeholder engagements and consensus building. Public-Private Partnership projects are long-term partnerships (typical projects have the duration between 20 and 40 years). Another distinctive feature of the PPP projects is the fact that the private partner carries the risk for the invested capital, not the public sector, as it is the case of projects based on outsourcing. PPP projects enable the risk to be optimally spread, and each subject of the partnership to take the risks they are able to manage best. The success of the policy in any nation or state is dependent on the level of commitment of the capitalist class and the willingness of the government to accelerate development for its people.

The practice of Public-Private Partnership (PPP) originated from the United States of America (USA), initially relating to joint public and private sector funding for educational programmes; and then in the 1950s to similar funding for utilities. It has come into wider use since the 1960s. It is referred to as public-private joint venture for urban renewal. It is also referred to as public funded provision of social service by non-public sector bodies often from the voluntary (not for profit) sector [12]. However, with the increasing dynamics and paradigm change in developmental approach, the policy has gained a wider appreciation and application in most developed and developing countries. In United Kingdom, Ireland, United States of America and India, PPP has been successfully used in the provision of infrastructures [6]. In Nigeria, implementation of the PPP in states likes Lagos, Bayelsa, Kaduna, and Abuja and most recently in Kogi state has yielded positive returns. It is to the credit of the Policy that the discovery of oil in Nigeria was made possible through the PPP Policy.

\section{The Kogi State Experience with the PPP}

Although Kogi state is among the earliest centers of development in Nigeria because of its role in the colonization of Nigeria, being the capital of colonial Nigeria and later a state in 1991, infrastructural development in the state was retarded as a result of which the inefficiencies of military rule terminated in 1999. Notwithstanding the formulation of Kogi PPP law, 2014, implementation remained at low ebb until the new direction administration of Governor Yahaya Bello on $14^{\text {th }}$ May 2016 operationalized the policy within the frame work of the Kogi state PPP legislation of 2014 which gave impetus to the establishment of the BP3 with Arc Roberts Moses Achanya as the pioneer director for the Bureau. The bureau was charged with the herculean task to conceptualize a PPP structure for the state, development of the structure and its implementation to facilitate the actualization of the $40 \%$ equity contribution of the total fund required for infrastructural development of Kogi state and to establish Kogi State as a PPP participating state, adding to the existing 11 PPP participating states in the country. The bureau adopted the PPP financing model by the institutionalization of the legal regulatory framework. The framework provides the necessary guide for:

- Initiating and developing public infrastructures and public assets development strategies for the state by means of public private partnerships

- Advising on policies that will promote and sustain public private, partnerships for provision and development of public infrastructures are public assets in the states.

- Formulating policies and regulatory frame work that will aid the implementation of this law and the operation of the public private partnership in the management of public infrastructures and public assets in the state.

- Co-coordinating policies and program of the state with respect to public private partnership for the provision and development of public assets in the states

- Ensuring that public private partnerships for the provision and development of public infrastructure or public assets in the state are in accordance with prevailing government policy and public interest.

The legal regulatory and institutional frameworks for the Kogi Bureau of Public Private Partnership (BP3) procurements are divided into six directorates in other to facilitate its functions. These six directorates includes; directorate of administration, and accounts, directorate of environment and social directorate of communication, training and public relations, Directorate of legal and contracting, directorate of finance and commercial and directorate of development and bidding. These directorates are operating within world best practices and delivering on mandates. The bureau has brought experience and professionalism to bear within two years of its establishment. It has positioned the state to compete favorably, in terms of PPP investments procurement and government to business facilitation. Infrastructural development and growth have skyrocketed in the last two years with the renovation of hitherto abandoned projects through this partnership.

Within the period of its establishments, the bureau has been able to among other things established PPP desk Offices across ministries, departments and agencies (MDAs) to facilitate PPP synergy among the MDAs. It has also developed procurement governance tools such as the Kogi state PPP guide lines, 2016, BP3 operational manual, as well as the state PPP solicitation procedures and screening template. It has 
domesticated the PPP law for the local governments through local government PPP gap, mapping and sensitization visits to most of twenty one local government areas of the state as well as the tertiary institution whose strategy documents is at advanced stage of completion for release and launch. The bureau in its short term of existence has processed over four hundred business proposals and has obtained executive assent for the implementation of over forty PPPs which are currently at various stages of completion.

On the security fronts, the Kogi state government has strengthened its partnership with paramilitary and other security organizations to ensure that the businesses of investors are protected. This singular gesture has earned him accolades from within and outside of Nigeria. The state has been given special recognition by the chief of army staff, general Buratai, inspector general of police, Ibrahim Idris. It is also on record that many envoys including the British high commissioner to Nigeria, Paul Wright, the United States ambassador to Nigeria, the head of the European Union delegation in Nigeria, General Aziz Kaikobad, have all expressed their readiness to invest in Kogi state through the PPP policy. This commitment is expected to blossom into large scale development for Kogi state in the next forceable decade. The imperativeness of security to economic development and growth cannot be over emphasized. Investors fear to grow their money in crises prone areas, the implementation of the PPP policy on security has made the state secure for business investment. When viewed from its abundant natural resources, the state has positioned itself as the most preferred region for investors. This breakthrough in PPP security implementation remains a landmark achievement for Kogi state in securing its future developments. Among all north and north central states, Kogi remains at the top of economically secured states. This is owing to the states implementation of the PPP model into its security sector.

On the infrastructural fronts the bureau has within its establishment concluded the structuring of over five high profile PPP investments. The confluence beach hotels which was the pride of the north central has remained moribund until recently when the bureau reached transaction close for a multinational investor who is already mobilizing over four billion naira to reengineer, turn around and manage the facility in a concession arrangement. Moreso the historic Mount Patti, an international asset for tourism which for years has been left unattended has now received attention through the PPP investment. The bureau in partnership with a multinational investor is building a world class hotel resort facility on the site. This project was flagged off during the Nigerian Vice President Yemi Osibanjo during the 2018 Kogi state economic and investment summit. This project when successfully executed will boost the tourism potentials of Kogi. The location of the mountain and the glory of nature it reveals especially that of the confluence between Benue and Niger rivers makes it desirable for tourists its transformation is capable of attracting tourist of international standard which will undoubtedly boost the economy of the state.

Similarly, the Bureau has made a breakthrough in the housing sector reform and development. The bureau has entered into contract with county links investment and properties limited a local investor for the development of Kogi satellite town. This project is aimed at providing an all-inclusive living environment for public servants while expanding and decongesting the Lokoja city line with the new town element of the long term infrastructure master plan development plan of the present administration. The plan is to construct two thousand five hundred houses to be up scaled to five hundred sitting in two hundred and fifty hectares of land along the crusher area in Lokoja. That project is already mobilizing for implementation and will provide the people a new choice of environment with opportunities for leisure and job opportunities for the teaming youths. This is also part of the PPP plan for urban transformation and decongestion of the capital city. There is also the state partnership with environment cleaners to ensure the sanity and cleanliness of the environment. The Geemoney cleaners through its partnership with the state have impacted reasonably on the environmental sanitation of Kogi state particularly within the state capital. A memorandum of understanding has been facilitated between the Kogi state government and Stratus consult limited by the Bp3 with an investment cost of 1.5 billion dollars for smart clean sustainable developmental projects on renewable energy and related environmental matters.

The state social investment program is receiving huge success as a private sector proponent has come up with a partnership plan to bring in about one billion naira progressively. Already 500 million naira has been approved and ten percent of that has been disbursed for implementation since the end of the economic summit. The scheme will boost the small and medium enterprises sector of the state. In the transport sector, a passenger protection plan has been procured and already implementing for impact. There is also an ongoing water transportation sector PPP strategy for the enhancement of water transportation in the state particularly along its major rivers. The 1 billion naira partnership project with Poka Global Resources and GNet Chemical limited has facilitated the management, maintenance and revenue collection for the greater Lokoja water supply. This project will also assist the capacity development for the state water board. In improving the transport situation of the state, the $\mathrm{Bp} 3$ has also entered a partnership with Prisma Nigeria limited.

The agricultural sector, conceivably have received more attention from the BP3 implementation. This is not unconnected with the vested interest of the government at boosting food production in the state. It will be recalled that the Governor launched the Agric Business PPP Strategy Document during the Agric summit marking his two year in office. That was a huge success for the ministry of agriculture. The bureau has since this establishment maximized the framework to get all investors for the best negotiation for the state in the area of food production. There is also the five hundred billion naira agricultural sector based food fermentation industry investment in Idah with expected value chain development for corn production. This project is been implemented in collaboration with Mijefa Nigeria limited. The Mijefa-Kogi food fermentation complex offshore program will provide ample opportunity for the farmers to go on large scale production with guaranteed off taker plans to avoid glut in the market. The bureau also facilitated the partnership with the International Transoil Corporation leading to the establishment of the confluence sugar company at Ibaji. The 198,748 billion dollars offshore investment is expected to boost employment generation, increase economic and commercial activities in Kogi state. The bureau has also facilitated a partnership with Ajifa Rice and Agro Allied Processing Co. Ltd, leading to the establishment of rice processing mill operations and management to boost rice production. This effort has already given rise to the confluence rice which is been consumed nationwide. Moreover, farmers in the state have been urged to form cooperative societies to benefit from the scheme. As an agrarian state with a huge focus on increased food production, oil plantations and other comparative advantage crops in the state are been revolutionized by the BP3. Investors as a result of the openness of the sector have indicated interest to partner with the state government leveraging on the $\mathrm{BP} 3$ policies on investment procurement 
to ensure adequate harnessing of the sector. The oil plantation concession transaction is already at the point of memorandum of understanding receiving valuable ministry input to commence operation.

\section{Conclusion}

Undoubtedly, with the implementation of this model of PPP, the Kogi State economy is now forward looking, security of investment has been guaranteed, foreign and local direct inflows and investment are on steady rise, public spending has drastically reduced for the emergent new Kogi. The establishment of the Kogi BP3 business and innovations desk presents the state with a unique win-win opportunity for the rapid economic transformation of the state. The success of this model or approach to development has prompted increased employment opportunities, increased economic and commercial activities, increased internally generated revenue for the state, increase in the net saving and foreign exchange, poverty reduction, provision of a ready market for Agric production as well as enhance long term investment in asset for Kogi which constitute the indices of economic development.

\section{References}

1. Kasim U, Okafor JI (2015) Public Private Partnership Policy (PPP) In Nigeria: An Overview. International Journal of Social Sciences and Humanities Reviews 5: 66-71.
2. Jacobs A (2018) Kogi is a huge investment Archipelago. Kogi BPP news (Years of Economic Modeling by the GYB Administration).

3. Sullivan A, Sheffrin MS (2003) Economics: Principles in action. Upper Saddle River, New Jersey, Pearson Prentice Hall.

4. Ugwu AO (2012) Assessing the viability of public-private partnership (PPP) as an option for infrastructural development in Nigeria: A Study Of Enugu State.

5. Olaopa T (2010) Innovation and Best Practices in Public Sector Reforms: Ideas, Strategies and Conditions. Ibadan: University Press Plc.

6. Oyedele OA (2014) Public-Private Partnership (PPP) and Infrastructure Provision in Nigeria. In AARCHES 2012 Biennial General Meeting and Annual Conference.

7. An Introduction to Public Private Partnership (2003) A Publication of Partnership British Columbia.

8. Hodge, Graves (2018) Cited in Private Sector Intervention in Environmental Management the KOGI Experience published in Kogi BPP news (Years of Economic Modeling by the GYB Administration).

9. Savas ES (2001) Privatisation and Public-Private Partnership, New Delhi: Affiliated East-West Press.

10. Private Partnership Reference Guide Version, 2.0 (2014) A publication of the International Bank for Reconstruction and Development/The World Bank, Asian Development Bank, and Inter-American Development Bank.

11. Public Private Partnerships: Benefits and Opportunities for Improvement within the United States, Syracuse University.

12. Asimiyu GA (2011) Towards a Public-Private Partnership in the Nigerian Power Sector: Challenges and Prospects. 